\title{
EFFECT OF DIFFERENT PRE-SOWING TILLAGE ON QUANTITY AND QUALITY OF PARSNIP (Pastinaca sativa L.) ROOT YIELD IN RIDGE CULTIVATION
}

\author{
Mirosław Konopiński, Lidia Nowak, Roman Mitura, Dorota Skiba \\ University of Life Sciences in Lublin, Department of Cultivation and Fertilization of Horticultural Plants, \\ Leszczyńskiego 58, 20-068 Lublin, Poland, e-mail: miroslaw.konopinski@up.lublin.pl
}

Received: 05.01.2011

\begin{abstract}
Parsnip is a very valuable vegetable due to its nutritional value and dietetic quality. It is moreover herbal raw material abundant in active substances. The yield quality of vegetables greatly depends on thorough pre-sowing soil tillage. The present study aimed at evaluating the influence of different presowing soil tillage (medium-deep ploughing, cultivating) and plant growing methods, flat or ridge cultivation, on the yield of parsnip and some biometric traits of its roots. The field experiment was carried out in 1999, 2000 and 2002 on lessive soil with the granulometric composition corresponding to medium silty loam. The parsnip cultivar 'Półdługi Biały' was the experimental plant species. The cultivation of parsnip on ridges had a significant influence on increased total yield of roots and decreased yield of small roots, as compared to flat cultivation. A significant increase in unit weight of the root and its diameter in the top part was also recorded in the latter type of cultivation. Spring pre-sowing tillage had no significant effect on parsnip yields. An increasing trend was observed only for total and marketable root yield in the ploughed plots. When parsnip is grown on lessive soil (which has an unstable structure), plants cultivated on ridges after spring pre-sowing plough are the most beneficial treatment combination.
\end{abstract}

Key words: Pastinaca sativa, tillage, plant cultivation method, yield quality

\section{INTRODUCTION}

Parsnip is a vegetable with a high nutritional value and dietetic quality. The storage roots of parsnip contain considerable amounts of sugars, proteins and vitamin $\mathrm{C}, \mathrm{B}_{1}, \mathrm{~B}_{2}$ and $\mathrm{B}_{6}$. The value of parsnip is also enhanced due to the content of fibre, minerals, including potassium, phosphorus, calcium, iron, as well as pectins (Orłowski and Kołota, 1999; Wolski et al. 1999; Ku skowska, 2000; Koł ota et al. 2007).
Parsnip is valuable as herbal raw material. Its herb, roots, and fruits contain many active substances such as essential oils, flavonoids, acetylene, and furanocoumarin compounds (D y d c h and Wolski, 1996).

The climatic and soil requirements of parsnip are not excessive; however, due to the fact that it is an oceanic climate species, it needs wet habitats ( $\mathrm{S} \mathrm{k}$ ą $\mathrm{p}$ ski and D ą brow ska, 1994). Water deficiency during its growing period strongly reduces plant growth and lowers yields, and moreover, it has a negative influence on the quality of harvested roots. Parsnip grows well on heavy and loamy soils, while higher yields can be achieved from habitats with good culture, humic ones, and non-crusting soils.

Root vegetables show a strong reaction to the way in which soil is prepared for sowing as well as to the plant cultivation method. Deep pre-sowing tillage determines the achievement of good quality yield of parsnip roots. Nevertheless, there are still attempts to introduce some tillage reduction consisting in the elimination of ploughing or making pre-sowing tillage more shallow (W ł o d e k et al. 1999; K o n o p i ń s k i et al. 1999; B łażewicz-W oźniak et al. 2001; Kęsik et al. 2006; Konopiński and Błażewi c z - W oźni a k, 2008).

The aim of the present study was to evaluate the influence of spring pre-sowing ploughing and shallow tillage (cultivating) as well as of plant cultivation methods, with parsnip grown on ridges or on flat ground, on its root yield and selected biometric traits of roots.

\section{MATERIALS AND METHODS}

The field experiment was carried out in 1999, 2000, and 2002 in the Felin Experimental Farm belonging to the University of Life Sciences in Lublin. 
The study was conducted on lessive soil developed from loess formations with the granulometric composition of medium silty loam. Parsnip (Pastinaca sativa L.), 'Półdługi Biały', was the experimental plant species. The experimental design included the following: two methods of pre-sowing tillage with cultivating (medium-deep ploughing - to $22 \mathrm{~cm}$ depth and cultivating - to $15 \mathrm{~cm}$ depth), as well as two methods of plant cultivation: ridge and flat cultivation. Mineral fertilization was applied at the following rates: $50 \mathrm{~kg} \mathrm{~N} \times \mathrm{ha}^{-1}$ prior to sowing and $50 \mathrm{~kg} \mathrm{~N} \times \mathrm{ha}^{-1}$ post-

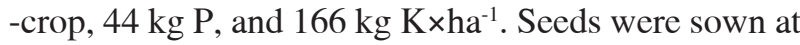
the end of April at an amount of $8 \mathrm{~kg} \times \mathrm{ha}^{-1}$ in rows with $50 \mathrm{~cm}$ spacing and to a depth of $2 \mathrm{~cm}$. The harvest of parsnip roots was done at mid-October.

The experiment investigated the effect of deep and shallow spring pre-sowing tillage as well as ridge and flat cultivation on total root yield, marketable root yield (root length above $20 \mathrm{~cm}$, root thickness in its top part above $14 \mathrm{~mm}$ ), yield of small roots, and some biometric traits of roots (unit weight, length, diameter).

The results were studied by means of variance analysis and the significance of differences was determined using Tukey's test at the 0.05 probability level.

\section{RESULTS AND DISCUSSION}

Total root yield. Regardless of the studied experimental factors, parsnip root yield amounted to $29.1 \mathrm{t}$ per 1 hectare (Table 1). Parsnip grown on ridges produced significantly higher total root yields (by $7.8 \mathrm{t} \mathrm{ha}^{-1}$ ) as compared to flat field cultivation. The positive influence of the cultivation of root vegetables on ridges was confirmed by other experiments carried out by K o n o pińs ki (2009) on purple salsify, which revealed significantly better yields on ridges than in flat field cultivation. Scorzonera also yielded better when grown on ridges (K o n o p i ń s k i, 2008). Carrot has been recommended for growing on ridges for many years (Taivalma and Talvitie, 1997; S a i ful-Is l a m et al. 1998; R u mpel and Grudzień, 2000; Sady and Cebulak, 2000; Wierzbicka et al. 2004). Babik and Skierkowski (1998) reported that, despite poor emergence, chicory and carrot yields from ridge cultivation were higher than from flat cultivation.

Different pre-sowing tillage methods applied in spring (medium-deep ploughing and cultivating), along with complementary tillage, had no significant influence on parsnip total root yields. Regardless of the cultivation method, more roots were harvested from the treatments with spring ploughing (by $0.8 \mathrm{t} \times \mathrm{ha}^{-1}$ on average) than from the plots in which cultivating was used. Experiments done by Kę s i k et al. (1999) revealed that spring ploughing produced better effects on root yields than shallow pre-sowing soil tillage in experiments involving parsley and beetroot. Considering the interaction of tillage with the plant cultivation method, parsnip grown on ridges after spring medium-deep ploughing with cultivating appeared to be the most beneficial cultivating treatment combination. Total root yield in this treatment was higher by $7.8{\mathrm{t} \times \mathrm{ha}^{-1}}^{-1}$ than in the least beneficial one - parsnip grown on flat ground after spring pre-sowing ploughing.

Marketable root yield. The yield of marketable roots amounted to $15.3 \mathrm{t}$ per 1 hectare, on average (Table 2). Parsnip grown on ridges had no significant influence on marketable root yield. Regardless of spring pre-sowing soil tillage, 0.2 tons more roots were harvested from the treatments with ridges than from flat cultivation. Similar results were obtained in the study by K o n o p i ń s k i (2008) with scorzonera: higher marketable root yields were harvested on ridges. Diverse spring tillage in parsnip cultivation did not have any significant effects on marketable yield of its roots. However, slightly more roots (by $0.3 \mathrm{t} \times \mathrm{ha}^{-1}$ ) were harvested from the plots where ploughing was applied. In experiments with beetroot, K o n o p i n s k i (1997) achieved the highest marketable root yield due to the application of cultivating in spring, while lower yields were recorded after spring ploughing. Parsley in the study carried out by B ł a ż e w i c z - W oź $\mathrm{n} \mathrm{i} \mathrm{a} \mathrm{k} \mathrm{(1998)} \mathrm{reacted} \mathrm{in} \mathrm{a} \mathrm{different} \mathrm{way} \mathrm{to} \mathrm{pre-sowing}$ tillage. Pre-sowing cultivation - as opposed to spring ploughing and the use of rotary tiller - had a negative influence on marketable yield of parsley roots. Among tillage and cultivation treatments applied for parsnip growing, ridges applied after pre-sowing plough tillage appeared to be the most beneficial for root yields. The marketable yield of parsnip roots in this treatment

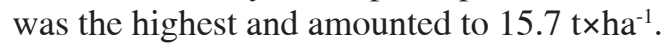

Yield of small roots. Regardless of the studied factors, the yield of small parsnip roots was $2.3 \mathrm{t} \mathrm{ha}^{-1}$ (Table 3 ). Harvested root yield was about $8.0 \%$ of total root yield. It was reported that the cultivation method had a considerable impact on the yield level of small roots. When plants grew on ridges, the amount of small roots was lower by $1.1 \mathrm{t} \mathrm{ha}^{-1}$ than in flat cultivation. The same correlation was reported by B abik and Skierkowski (1998), who found less bent and small roots in chicory and carrots cultivated on ridges compared to those from flat cultivation. A slightly lower yield of small parsnip roots (by $0.3 \mathrm{t} \times \mathrm{ha}^{-1}$ ) was harvested from the plots where cultivating was applied in spring. Among of the tested cultivation combinations, growing on ridges after spring cultivating of the soil was characterized by the lowest yields of small roots.

Single root weight. The studied plant cultivation methods had a significant effect on unit weight of the parsnip root (Table 4). It was found that ridge cultivation resulted in a significant increase in root weight, which was by $82 \mathrm{~g}$ higher than the unit weight of roots 
harvested from the flat field. Pre-sowing tillage played a remarkable role - although not proved statistically in determining the root weight. Reduced spring tillage, by applying shallow ploughing and cultivating, had a negative effect on the unit weight of the parsnip root. Regardless of the cultivation method, the unit weight of the roots harvested from the cultivated plots was lower than that of the roots from the ploughed plots. Parsley reacted in a different way to spring cultivating in the experiments performed by $\mathrm{B} \nmid \mathrm{a} \dot{\mathrm{z}} \mathrm{e} \mathrm{w}$ i c z - W o ź $\mathrm{niak}$ (1998). The roots of the plants from the treatments after pre-sowing soil cultivating were characterized by higher weight. Among the tillage treatments under investigation, parsnip cultivation on ridges after spring ploughing appeared to be the best in terms of root weight. The average unit root weight from this treatment was $247 \mathrm{~g}$, while the lowest value of this trait was recorded for flat field cultivation after spring ploughing (124 g, on average).

Root length. Regardless of the studied experimental factors, the mean root length was $239 \mathrm{~mm}$ (Table 5). Ridge cultivation had more beneficial effects (but not proved statistically) on parsnip root development. Roots harvested from ridges were longer than those from flat soil. Similar results were reported by Rumpel and Grudzień (2000) when studying carrot cultivation. These authors found that when carrot was grown on ridges, higher and better-quality yields could be achieved. Roots were longer and with a better shape. The same conclusions were drawn by $\mathrm{D}$ y śk o and Kaniszewski (2007) from experiments with carrot. Significantly longer black salsify roots in ridge cultivation, as opposed to flat cultivation, were obtained by Konopinski (2003). Regardless of the parsnip cultivation method, a significantly better effect of spring ploughing on root growth was recorded. Plough tillage resulted in roots by $30 \mathrm{~mm}$ longer compared to those harvested from the cultivated plots. Also, the longest parsley roots were produced after spring ploughing in the experiments done by $\mathrm{B} \nmid \mathrm{a} \dot{\mathrm{z}} \mathrm{e} \mathrm{w} \mathrm{i} \mathrm{c} \mathrm{z-}$ - W o źn i a k (1998). Both in ridge and flat cultivation of parsnip, spring ploughing had much better effects on the value of this parameter than cultivating.

Root diameter in the top part. The applied plant cultivation methods had a significant influence on parsnip root diameter in its top section (Table 6). It was found that ridge cultivation produced better conditions for root growth, which was manifested in a 10 $\mathrm{mm}$ larger root diameter compared to flat cultivation. A positive impact of ridge cultivation on root thickness was also reported for scorzonera (Kon op iński , 2003). The experiments with parsnip also revealed that spring ploughing tended to have a positive effect on the root diameter. In the plough tillage treatments, the mean parsnip root diameter was larger by $4 \mathrm{~mm}$ than in the plots in which cultivating was used. A similar correlation was observed in the case of scorzonera cultivation (K o n o p i ń s k i , 2003). Considering the examined factors, it should be concluded that plant cultivation on ridges after pre-sowing plough tillage was the best combination for this trait, because the average root diameter in its top part was $61 \mathrm{~mm}$.

Table 1.

Effect of tillage and plant cultivation method on total yield of parsnip roots in $\mathrm{t} \times \mathrm{ha}^{-1}$ (mean for 1999-2002)

\begin{tabular}{lccc}
\hline \multirow{2}{*}{$\begin{array}{c}\text { Spring } \\
\text { pre-sowing tillage }\end{array}$} & Plant cultivation method & Mean \\
\cline { 2 - 3 } & ridge cultivation & flat cultivation & 29.5 \\
\hline Ploughing & 33.9 & 25.1 & 28.7 \\
Cultivating & 32.1 & 25.3 & 29.1 \\
\hline Mean & 33.0 & 25.2 & 6.0 \\
\hline $\operatorname{LSD}_{(0.05)}$ for plant cultivation method & & & $\mathrm{ns}$ \\
$\operatorname{LSD}_{(0.05)}$ for pre-sowing tillage & & & \\
\hline
\end{tabular}

Table 2

Effect of tillage and plant cultivation method on the marketable yield of parsnip roots in $\mathrm{t} \times \mathrm{ha}^{-1}$ (mean for 1999-2002)

\begin{tabular}{lccc}
\hline \multirow{2}{*}{$\begin{array}{c}\text { Spring } \\
\text { pre-sowing tillage }\end{array}$} & \multicolumn{2}{c}{ Plant cultivation method } & Mean \\
\cline { 2 - 3 } & ridge cultivation & flat cultivation & 15.4 \\
\hline Ploughing & 15.7 & 15.2 & 15.2 \\
Cultivating & 15.1 & 15.2 & 15.3 \\
\hline Mean & 15.4 & 15.2 & $\mathrm{~ns}$ \\
\hline $\operatorname{LSD}_{(0.05)}$ for plant cultivation method & & & $\mathrm{ns}$ \\
$\mathrm{LSD}_{(0.05)}$ for pre-sowing tillage & & & \\
\hline
\end{tabular}


Table 3.

Effect of tillage and plant cultivation method on the yield of small parsnip roots in $\mathrm{t} \times \mathrm{ha}^{-1}$ (mean for 1999-2002)

\begin{tabular}{lccc}
\hline \multirow{2}{*}{$\begin{array}{c}\text { Spring pre-sowing } \\
\text { tillage }\end{array}$} & \multicolumn{2}{c}{ Plant cultivation method } & Mean \\
\cline { 2 - 4 } & ridge cultivation & flat cultivation & 2.5 \\
\hline Ploughing & 1.8 & 3.2 & 2.2 \\
Cultivating & 1.7 & 2.6 & 2.3 \\
\hline Mean & 1.8 & 2.9 & 1.1 \\
\hline $\operatorname{LSD}_{(0.05)}$ for plant cultivation method & & & $\mathrm{ns}$ \\
$\operatorname{LSD}_{(0.05)}$ for pre-sowing tillage & & & \\
\hline
\end{tabular}

Table 4.

Effect of tillage and plant cultivation method on the weight of the parsnip root in $g$ (mean for 1999-2002)

\begin{tabular}{lccc}
\hline \multicolumn{1}{c}{$\begin{array}{c}\text { Spring pre-sowing } \\
\text { tillage }\end{array}$} & \multicolumn{2}{c}{ Plant cultivation method } & Mean \\
\cline { 2 - 4 } & ridge cultivation & flat cultivation & 186 \\
\hline Ploughing & 247 & 124 & 147 \\
Cultivating & 167 & 126 & 166 \\
\hline Mean & 207 & 125 & 52.4 \\
\hline $\operatorname{LSD}_{(0.05)}$ for plant cultivation method & & & $\mathrm{ns}$ \\
$\operatorname{LSD}_{(0.05)}$ for pre-sowing tillage & & & 167 \\
\hline
\end{tabular}

Table 5.

Effect of tillage and plant cultivation method on the length of the parsnip root in mm (mean for 1999-2002)

\begin{tabular}{lccc}
\multicolumn{1}{c}{$\begin{array}{c}\text { Spring pre-sowing } \\
\text { tillage }\end{array}$} & \multicolumn{2}{c}{ Plant cultivation method } & Mean \\
\cline { 2 - 4 } & ridge cultivation & flat cultivation & 254 \\
\hline Ploughing & 262 & 245 & 224 \\
Cultivating & 221 & 227 & 239 \\
\hline Mean & 242 & 236 & $\mathrm{~ns}$ \\
\hline $\operatorname{LSD}_{(0.05)}$ for plant cultivation method & & & 19.1 \\
$\operatorname{LSD}_{(0.05)}$ for pre-sowing tillage & & \\
\hline
\end{tabular}

Table 6.

Effect of tillage and plant cultivation method on the diameter of the parsnip root in its top part in mm (mean for 1999-2002)

\begin{tabular}{|c|c|c|c|}
\hline \multirow{2}{*}{$\begin{array}{l}\text { Spring pre-sowing } \\
\text { tillage }\end{array}$} & \multicolumn{2}{|c|}{ Plant cultivation method } & \multirow{2}{*}{ Mean } \\
\hline & ridge cultivation & flat cultivation & \\
\hline Ploughing & 61 & 46 & 54 \\
\hline Cultivating & 53 & 47 & 50 \\
\hline Mean & 57 & 47 & 52 \\
\hline $\operatorname{LSD}_{(0.05)}$ for plant cultivation method & & & 6.8 \\
\hline $\mathrm{LSD}_{(0.05}$, for pre-sowing tillage & & & ns \\
\hline
\end{tabular}




\section{CONCLUSIONS}

Parsnip cultivation on ridges had a significant influence on the increase in total root yields and the decrease in the yield of small roots as compared to flat cultivation. A significant increase in the unit weight of the root and the diameter in its top was recorded as well.

Spring pre-sowing tillage did not exert any significant effect on parsnip yield. An increasing tendency for total and marketable root yield was only observed in the treatments with plough tillage. Spring ploughing - as compared to cultivating - had a significant impact on parsnip root elongation.

The most beneficial method for parsnip grown on lessive soil with an unstable structure is ridge cultivation after spring pre-sowing ploughing.

\section{REFERENCES}

Babik J., Skierkowski J., 1998. Uprawa (marchwi i cykorii) płaska, czy na redlinach?. OWK, 7: 9 (in Polish)

Błażewicz-Woźniak M., 1998. Wpływ czynników agrotechnicznych na wschody, wzrost i plonowanie pietruszki korzeniowej, uprawianej na glebie o nietrwałej strukturze. Część III. Plon korzeni i jego struktura. / Effect of some agrotechnical factors on emergence, growth and yield of parsley, cultivated on soil subject to puddling. Part III. Yield of roots and its structure. Ann. Univ. Mariae Curie-Skłodowska, VI, EEE:73-86 (in Polish)

Błażewicz-Woźniak M., 1998. Wpływ czynników agrotechnicznych na wschody, wzrost i plonowanie pietruszki korzeniowej, uprawianej na glebie o nietrwałej strukturze. Część IV. Cechy jakościowe korzeni. I Effect of some agrotechnical factors on emergence, growth and yield of parsley, cultivated on soil subject to puddling. Part IV. Quality features of roots. Ann. Univ. Mariae Curie-Skłodowska, VI, EEE: 89-101 (in Polish)

Błażewicz-Woźniak M., Kęsik T., Konopiński M., 2001. Kształtowanie się agregacji gleby pod warzywami w uproszczonym systemie uprawy roli. / Soil aggregates formation under vegetables in soil reduced cultivation system. Acta Agroph. 45: 5-15 (in Polish)

Dyduch J., Wolski T., 1996. Seasonal increase in biomass and changes in photochemical composition of parsnip organs (Pastinaca sativa L.). Part I. Biomass increase in plants. Umbelliferae Improvement Newsletter, 6: 13-15.

Dyśko J., Kan is zewski S., 2007. Effect of drip irrigation, $\mathrm{N}$-fertigation and cultivation methods on the yield and quality of carrot. Veg. Crops Res. Bull. 67: 25-33.

Kęsik T., Konopiński M., Błażewicz-Woźniak M., 1999. Wpływ zabiegów agrotechnicznych na wschody i plonowanie warzyw korzeniowych. / Effect of agrotechnical factors on emergence and yielding of root vegetables. Zesz. Prob. Post. Nauk Rol., 466: 259-270 (in Polish)
Kęsik T., Konopiński M., Błażewicz-Woźn i a k M., 2006. Wpływ uprawy przedzimowej i mulczu z roślin okrywających na retencję wody, zagęszczenie i porowatość dyferencyjną gleby po przezimowaniu. / Effect of pre-winter soil tillage and cover crop mulches on water retention, compaction and differential porosity of soil after winter time. Acta Agroph. 7 (4): 915-926 (in Polish)

Kołota E., Orłowski M., Biesiada A., 2007. Warzywnictwo. Wydanie II. Pasternak zwyczajny (Pastinaca sativa L.). Wydawnictwo Uniwersytetu Przyrodniczego we Wrocławiu.: 286-288 (in Polish)

Konopiński M., 1997. Wpływ zróżnicowanej przedsiewnej uprawy roli na niektóre właściwości fizyczne gleby, zachwaszczenie oraz plonowanie cebuli i buraka ćwikłowego. Część II. Plonowanie cebuli i buraka ćwikłowego. / Effect of differentiated pre-sowing cultivation on some physical properties of the soil, weed infestation and the yielding of onion and red beet. Part II. Yielding of onion and red beet. Ann. Univ. Mariae Curie-Skłodowska, V, EEE: 157-165 (in Polish)

Konopiński M., Kęsik T., Błażewicz-Woźniak M., 1999. Wpływ zróżnicowania wiosennej przedsiewnej uprawy roli pod warzywa na niektóre fizyczne właściwości gleby. / Influence of differentiated spring pre-sowing soil tillage on some physical properties of the soil. Zesz. Prob. Post. Nauk Rol. 466: 271-279 (in Polish)

Kono piński M., 2003. Wpływ zróżnicowanych systemów uprawy na kształtowanie warunków wzrostu, plonowanie i wartość biologiczną skorzonery (Scorzonera hispanica L.). Rozprawy Naukowe Akademii Rolniczej w Lublinie, Wydział Ogrodniczy: 271 (in Polish)

Konopiński M., 2008. The effect of different soil and plant cultivation methods on yield and chemical composition of scorzonera roots. Veg. Crops Res. Bull., 68: 101-110.

Konopiński M., Błażewicz-Woźniak M., 2008. Wpływ zróżnicowanej przedsiewnej uprawy roli i międzyplonów na wschody i plonowanie roślin korzeniowych. / Effect of differentiated pre-sowing soil tillage and intercrops on the emergence and yield of root plants. Zesz. Prob. Post. Nauk Rol. 527: 155-163 (in Polish)

Konopiński M., 2009. Influence of intercrop plants and varied tillage on yields and nutritional value of salsify (Tragopogon porrifolius L.) roots. Acta Sci. Pol. Hortorum Cultus, 8 (2): 27-36.

Kuskowska M., 2000. Pasternak zwyczajny jako wartościowa roślina warzywna i pastewna. I Parsnip as a valuable vegetable and fodder plant. Biul. Nauk. UWM Olsztyn, 8: 257-262 (in Polish)

Orłowski M., Kołota E., 1999. Pasternak. Uprawa warzyw. Wyd. BRASIKA, Szczecin: 208-210 (in Polish).

Rumpel J., Grudzień K., 2000. Lepsza jakość marchwi $\mathrm{z}$ redlin. / Better quality of carrot from the ridges. Top Agrar Polska, Mag. Nowocz. Rol. 3: 78-82 (in Polish) 
Sady W., Cebulak T., 2000. The effect of irrigation and cultivation methods on some mineral compounds in storage roots of the carrot. Folia Hortic. 12 (2): 35-41.

Saiful-Islam A.F.M., Kitaya Y., Yanase M., Mori G., Kiyota M., 1998. Growth characteristics and yield of carrots grown in a soil ridge with a porous tube for soil aeration in a wet lowland. Scientia Hortic. 77 (1/2): 117-124.

Taivalmaa S.L., Talvitie H., 1997. The effect of ridging, row-spacing and seeding rate on carrot yield. Agric. Food Sci. Finl., 6 (5/6): 363-369.

Wierzbicka B., Pierzynowska-Korniak G., Majkowska-Gadomska J., 2004. Effect of cultivation method and storage on the yield and turgor of storage roots of two carrot varieties. Fol. Univ. Agricult. Stein. Agricultura, 95 : 415-418.

Włodek S., Pabin J., Biskupski A., Kaus A., 1999. Skutki uproszczeń uprawy roli w zmianowaniu. / Effects of tillage simplifications in the rotation. Fol. Univ. Agricult. Stein. Agricultura, 195 (74): 39-45 (in Polish)

Wolski T., Dyduch J., Baj T., 1999. Ocena składu chemicznego kilku odmian pasternaku zwyczajnego (Pastinaca sativa L.) ze szczególnym uwzględnieniem odmiany Półdługi Biały. / Evaluation of the chemical composition of several parsnip cultivars (Pastinaca sativa L.) with special emphasis on 'White Parsnip' cultivar. Zesz. Prob. Post. Nauk Rol. 466: 237-248 (in Polish)

\section{Wpływ zróżnicowanej przedsiewnej uprawy roli na wielkość i jakość plonu korzeni pasternaku (Pastinaca sativa L.) w uprawie na redlinach}

\author{
Streszczenie
}

Pasternak należy do bardzo cennych warzyw ze względu na wartość odżywczą i walory dietetyczne. Jest też bogatym w substancje czynne surowcem zielarskim. Jakość plonowania warzyw korzeniowych zależy w dużej mierze od starannej przedsiewnej uprawy roli. Celem przeprowadzonych badań było określenie wpływu zróżnicowanej przedsiewnej uprawy roli (orka średnia, kultywatorowanie) oraz uprawy roślin na redlinach i na płask, na plonowanie pasternaku i niektóre cechy biometryczne jego korzeni. Doświadczenia polowe przeprowadzono w latach 1999, 2000, 2002, na glebie płowej o składzie mechanicznym odpowiadającym glinom średnim pylastym. Rośliną doświadczalną był pasternak odmiany Półdługi Biały. Uprawa pasternaku na redlinach miała istotny wpływ na zwiększenie plonu korzeni ogółem oraz zmniejszenie plonu korzeni drobnych w porównaniu $\mathrm{z}$ uprawą na płask. W uprawie tej zanotowano istotny wzrost masy jednostkowej korzenia oraz jego średnicy w części głowowej. Wiosenna przedsiewna uprawa roli nie wywierała istotnego wpływu na plonowanie pasternaku. Zaobserwowano jedynie tendencję wzrostową plonu korzeni ogółem i handlowych w obiektach $\mathrm{z}$ uprawą płużną. Orka wiosenna, w porównaniu z kultywatorowaniem, miała natomiast istotny wpływ na zwiększenie długości korzeni. Na glebie płowej o nietrwałej strukturze, najkorzystniejszą kombinacją uprawową jest uprawa pasternaku na redlinach, po wiosennej orce przedsiewnej. 